\title{
SELF-EMPLOYMENT OF FOREIGNERS AS AN INNOVATIVE SOLUTION ON THE LABOR MARKET IN THE EUROPEAN UNION
}

\author{
Valentinas NAVICKAS ${ }^{1 *}$, Eva GRMANOVÁ2 ${ }^{2}$, Waldemar GAJDA ${ }^{3}$ \\ 1, 2 Alexander Dubček University of Trenčin, Faculty of Social and Economic Relations, Slovakia \\ ${ }^{3}$ Warsaw Management School - Graduate and Postgraduate School, Warsaw, Poland
}

Received 10 December 2019; accepted 10 January 2020

\begin{abstract}
The main aim of this article is to identify certain specificity in self-employment of foreigners in EU countries and to find out whether the differences in self-employment of foreigners between countries are diminishing. Within the main objective, we have set two sub-objectives. The first sub-objective is to compare EU countries on the basis of the following indicators: $1 /$ number of self-employed foreigners and 2/ share of self-employed foreigners in employed persons from foreign countries. The second sub-objective is to determine whether EU countries converge in the number of the share of self-employed foreigners in the number of employed persons from foreign countries. We have confirmed that the countries have a tendency to convergence in regard to the share of self-employed foreigners in employed persons from foreign countries. We assume that this tendency can also be due to the pressure of the labour market that shows a lack of labour force. The share of self-employed migrants is relatively high in Eastern Europe. On the other hand, their increase is below average compared to the EU.
\end{abstract}

Keywords: migration, self-employment, foreigners, immigrants, beta-convergence, correlation diagram, European Union.

JEL Classification: J61.

\section{Introduction}

Currently, migration is a topical issue of many countries. The advantages and disadvantages of migration are being analysed. In literature, migrants' reasons for immigration are divided into two groups. "Push factors" are represented by negative domestic conditions that motivate individuals to seek work abroad. "Pull factors" can be described as positive conditions in the countries of destination that make them more attractive for potential migrants (Čajka, Jaroszewicz, \& Strielkowski, 2014).

Demographic development in less developed countries differs from developed countries. The number of immigrants and the share of immigrants vary from country to country. Important influencing factors are the economic situation and migration policy of the countries. The largest absolute numbers of immigrants are in economically developed countries such as Germany and the United Kingdom (Simionescu et al., 2017).

Vice versa, lower numbers of immigrants have countries with lower levels of economic development. The countries with low immigration include Slovakia. Immigration in the Slovak Republic is influenced by lower levels of economic and social development (Krajňáková \& Vojtovič, 2017).

The structure of immigrants entering the EU and their involvement in the working and cultural life of a particular country is significant too. Their unemployment burdens the social system. On the other hand, employment of immigrants can bring many positive results. One of them is the fact that the presence of immigrants leads to an increase in work effectiveness in strategic sectors (Skibiński \& Rączaszek, 2017). In general, we can say that a large number of immigrants are coming to the European Union. Finding new solutions to migration policy across the EU and its individual countries is very topical nowadays. Attitudes are being sought to turn immigrant flows into positive phenomena and to solve some serious problems connected with the arrival of immigrants in the EU. Immigration trends should be monitored. They should be used as a basis for migration policy (Lapshyna, 2012).

*Corresponding author. E-mail: valentinas.navickas@ktu.lt 


\section{Literature review}

Migration flows are greatly affected by labour migration. Greater mobility of the work force is the result of globalisation processes (Fratczak, 2016). According to Jurčová (2008), articles on labour migration can be divided into three groups: $1 /$ articles that examine migration in a complex way and labour migration is part of them, $2 /$ articles where labour migration is the main focus, $3 /$ articles on migration where specific issues of labour migration are addressed.

Articles on labour migration focus on different areas the whole of the EU (Refslund, 2017) or individual European countries (Bargerová, 2016; Streimikiene et al., 2016).

Labour migration is addressed mainly in terms of trends and reasons (Fraňková, 2015; Reja \& Das, 2019). Many authors emphasize the economic causes of labour migration. Economically developing countries attract labour force (Świerczyńska \& Kliber, 2018). According to De Luna Gallardo, Korneeva, and Strielkowski (2016) there are mostly economic reasons why labour force decides to find higher incomes and better working conditions in the labour markets of destination. Many authors emphasize working conditions. The main factor of labour migration is differences between wage in the country the migrants are leaving from and potential wage in the country of destination. The mentality of migrants plays a significant role too (Vdovtsova, 2008; Libanova, 2019).

Labour migration has many benefits, but can be detrimental too. Employment is the biggest determinant of migrants' net fiscal contribution. Immigrants contribute considerably to labour-market flexibility (OECD, 2014). Immigration increases the labour force of the country of destination. Immigrant workers affect average wages in the economy (S. P. Kerr \& W. R. Kerr, 2011).

Working immigrants can have an impact on the expansion of migratory flows. If immigrants take up employment in a foreign country, their family members and friends will have a higher possibility of migration too (Bahna, 2012; Bilan, 2012).

The advantages and disadvantages of immigrant workers vary in individual professions. Jenkins et al. (2010) examines international migration of psychiatrists. According to the authors, migration of health professionals from countries with low and middle income to rich countries has a detrimental effect on the health system of the migrants' country. The doctors from Central and Eastern Europe will continue to leave. The demand for doctors will continue to grow (P. Zuk, P. Zuk, \& Lisiewicz-Jakubaszko, 2019).

Immigrant workers tend to do business more than the domestic population. In Europe, there is a higher rate of self-employment than in Southern Europe and in the countries of Central and Eastern Europe. One reason for this are flexible visa regulations for immigrant entrepreneurs and the employment situation in these countries. Immigrants' enterprises become bankrupt more often than enterprises of the domestic population (European Economic and Social Committee, 2012).
Self-employment of immigrants is negatively affected by several factors. These include: frequent changes in legislation, large bureaucracy, language barrier, reluctance of state authorities and others (Slovak Business Agency, 2019). In general, an open economy, adapted to legislation and governmental processes, can have a significant impact on the process of self-employment of migrants. On the other hand, the obstacle of self-employment immigrants is inflexible and often changing legislation.

\section{Aim, data and research methodology}

\subsection{Aim and data}

There are large differences in the number of immigrants living in the territory of individual EU countries and there are also large differences in economic immigration. The aim of the EU migration policy is to reduce these disparities.

The consequences of immigration are linked to the reasons for the migrants' choice of destination country, as well as their efforts and abilities to participate in the labour market. It is important for individual countries that immigrants find the best possible place in the labour market and a suitable way of employment. One of the forms is employment itself.

We will focus on self-employment of foreigners within the EU and will examine the specifics of individual EU countries. The main aim of this article is to identify a certain specificity in the self-employment of foreigners in EU countries and to find out whether the differences in self-employment of foreigners between countries are diminishing. Within the main objective, we have set two sub-objectives. The first sub-objective is to compare EU countries on the basis of the following indicators: 1/ number of self-employed foreigners and 2/ share of selfemployed foreigners in the number of employed persons from foreign countries. The second sub-objective is to determine whether EU countries converge in the share of self-employment of foreigners in employed persons from foreign countries. Then we will divide the EU countries according to the initial state and the growth of the share of self-employment of foreigners in employed persons from foreign countries.

Due to the availability of data in the Slovak Republic only from certain years, we focused mainly on the period from 2010 to 2016. Data were obtained from the Eurostat database $(2019,1,2)$.

\subsection{Research methodology}

We used the beta convergence method to analyse the convergence of self-employment of foreigners in EU countries.

\section{Beta convergence}

According to Minariik et al. (2013), beta convergence is based on the assumption that units in the period analysed according to a specific indicator converge, if units having low indicator values at the beginning of the period show 
faster growth than units with higher indicator values at the beginning of the period. In our case, the units are EU countries.

Unit growth over the analysis period is expressed by the average growth coefficient.

The average growth coefficient will be calculated as

$$
\bar{k}=T-1 \sqrt{\frac{y_{T}}{y_{1}}},
$$

whereas: $y_{1}$ is the value in the first year (in period 1); $y_{T}$ is the value in the $T$-year of the period analysed (in pe$\operatorname{riod} T$ ).

According to Minařik et al. (2013), beta convergence is performed as follows:

- collecting data at the beginning and end of the period analysed and their logarithmic calculation in order to remove asymmetry,

- expressing the average growth coefficient for each unit,

- constructing a graph with a dependent variable - logarithms of average growth coefficients and with an independent variable - logarithms of initial values,

- determining linear regression function parameters using the least squares method with a dependent variable - logarithms of average growth coefficients and with an independent variable - logarithms of initial values,

- determining function monotony. If the linear function is declining, tendency to convergence prevails. If the linear function is increasing, tendency to divergence prevails.

- expressing the determination coefficient. The closer its value to $100 \%$, the stronger the tendency.

- the method can be supplemented by a correlation diagram It's a graph with a dependent variable - logarithms of the average growth coefficients and with the independent variable - logarithms of initial values, in which the points are divided by two perpendicular lines that cross the arithmetic mean of the dependent variable and the arithmetic mean of the independent variable. Thus, four groups of points are created.

\section{Research results and discussion}

\subsection{Comparison of EU countries according to self-employed foreigners}

The number of self-employed foreigners depends on the number of foreigners employed. This varies from one EU country to another. The highest number of foreigners employed is mainly in the economically most efficient countries.

Between 2010 and 2016, the number of foreigners employed across the EU increased. In 2010 there were 13919.7 thousand foreigners employed, in 2016 there were 16873.3 thousand foreigners employed. Based on the expression of descriptive statistics we can conclude that the mean and standard deviation of employed persons from a foreign country increased too. Thus, variability among EU countries as measured by standard deviation increased. The largest number of employed persons from a foreign country had Germany. Germany is an attractive country for foreigners mainly because of its economic performance. On the contrary, Croatia had the smallest number of employed persons from a foreign country. The descriptive statistics of persons employed from a foreign country in the EU, aged 15 to 64 years, are shown in Table 1 .

Table 1. Descriptive statistics of persons employed from a foreign country in the EU from 15 to 64 years (in thousand) (source: own processing in Statistica)

\begin{tabular}{|c|c|c|c|c|}
\hline & Mean & Min & Max & Standard deviation \\
\hline 2010 & 515.54 & 3.40 & 2972.80 & 862.10 \\
\hline 2016 & 624.94 & 2.80 & 4353.10 & 1120.26 \\
\hline
\end{tabular}

Eurostat monitors self-employment of foreigners in the context of the integration of migrants in the EU (Eurostat 2019, 1 - lfsa_esgan). Based on the Eurostat database we can say that the highest number of selfemployed foreigners was in Germany in 2010 and in the United Kingdom in 2016. Slovakia had the second lowest number of self-employed foreigners in 2016 (2.2 thousand). Lower values had only Lithuania (1.5 thousand), and in most EU countries, the number of self-employed foreigners increased from 2010 to 2016 . The largest relative increase was in Malta, where the number of self-employed foreigners rose by $500 \%$. The indicator analysed decreased only in six EU countries, namely in Greece, Cyprus, Hungary, Portugal, Slovakia and Sweden. The biggest relative decrease was in Greece, where the number of self-employed foreigners decreased to $58 \%$. In Slovakia, the number of self-employed foreigners decreased to $96 \%$. However, data from Bulgaria, Croatia, Lithuania (2010) and Romania were not available. Figure 1 shows the number of self-employed foreigners.

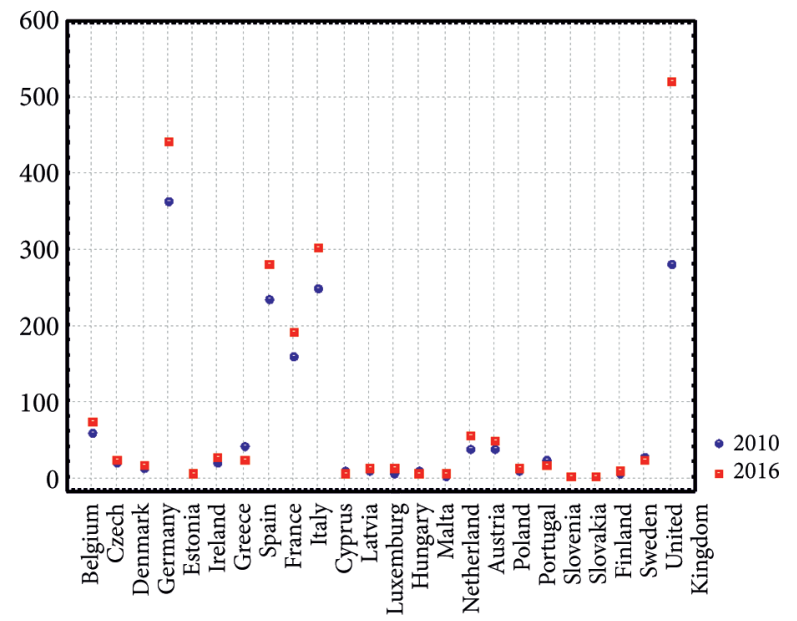

Figure 1. Self-employed foreigners in thousand, citizens from foreign countries aged 5 to 64 (source: own processing according to Eurostat) 
Based on the number of employed persons from foreign countries, in 2010 and 2016 we expressed the percentage share of self-employed foreigners in employed persons from foreign countries. Data are in Table 2. Relative data show that the largest share of self-employed foreigners in employed persons from foreign countries was in Slovakia. Thus, even though the absolute number of self-employed foreigners in the SR was the second lowest in the EU, the share of self-employed foreigners in employed persons from foreign countries was the highest in the SR from all the EU countries analysed. Poland, the Czech Republic and Hungary also had a large share of self-employed foreigners in employed persons from foreign countries.

By 2016, most of the EU countries analysed recorded a decline in the values of the indicator analysed. The biggest decline was in Slovenia, where the values dropped to $47.99 \%$. In the Slovak Republic, there was a decrease to $69.13 \%$ by 2016 . Nevertheless, the share of self-employed foreigners in employed persons from foreign countries remained the highest in Slovakia. The biggest increase of the indicator analysed was in Latvia, where the values increased to $165.15 \%$ in the period from 2010 to 2016 .

\subsection{Convergence of EU countries in self-employed foreigners}

To meet the second sub-objective, we used the beta convergence method. The linear regression function and correlation diagram are in Figure 2.

The linear regression function is

$$
\log y=0.065-0.0599 \log x .
$$

The regression coefficient of the linear regression function is a negative number $(-0.0599 / \mathrm{p}=0.0009)$. The

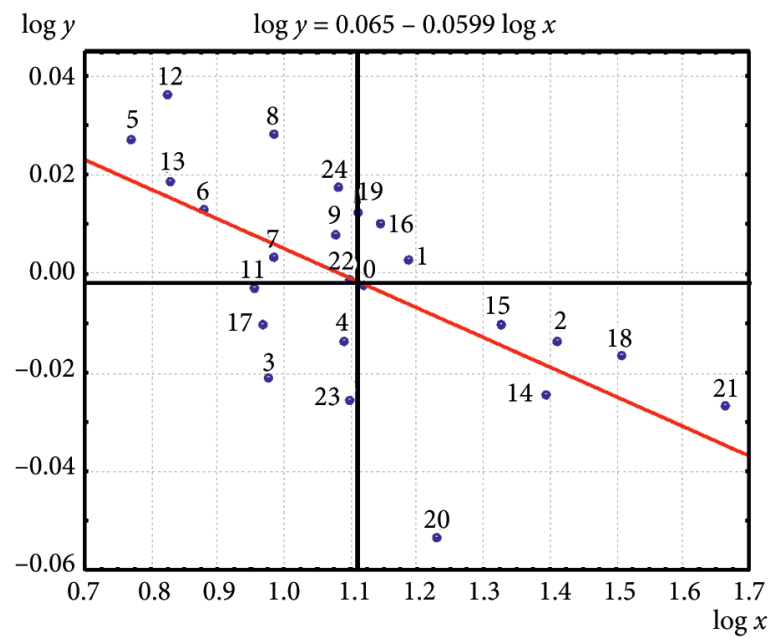

Belgium (1), Czech Republic (2), Denmark (3), Germany (4), Estonia (5), Ireland (6), Greece (7), Spain (8), France (9), Italy (10), Cyprus (11), Latvia (12), Luxembourg (13), Hungary (14), Malta (15), Netherland (16), Austria (17), Poland (18), Portugal (19), Slovenia (20), Slovakia (21), Finland (22), Sweden (23), United Kingdom (24)

Figure 2. Correlation diagram (source: own processing in Statistica)
Durbin-Watson statistic is $2.46(d u=1.45,4-d u=2.55)$. The Shapiro-Wilk statistic is $0.9214(p=0.0628)$. Error term has zero mean. The coefficient of determination is $40.20 \%$. The linear function is declining, a trend in regard to the share of self-employment of foreigners in employed persons from foreign countries towards convergence of the EU countries prevails. This finding may also be the result of labour shortages becoming apparent on labour markets. States are taking measures to increase the number of working immigrants.

In order to obtain information on the trend in the share of self-employment of foreigners in employed persons from individual countries, we have drawn up a correlation diagram.

After dividing the countries into groups in the correlation diagram (Table 3), we can determine some of their trends.

Table 2. Self-employed persons in \%, citizens from foreign countries aged 15 to 64 (source: Eurostat and own processing)

\begin{tabular}{|c|c|c|c|}
\hline EO/TIME & 2010 & 2016 & $I_{2016 / 2010}(\%)$ \\
\hline Belgium & 15.34 & 15.95 & 103.97 \\
\hline Bulgaria & - & - & - \\
\hline Czech Republic & 25.73 & 21.44 & 83.34 \\
\hline Denmark & 9.43 & 7.06 & 74.85 \\
\hline Germany & 12.22 & 10.17 & 83.18 \\
\hline Estonia & 5.88 & 8.58 & 146.06 \\
\hline Ireland & 7.54 & 9.06 & 120.17 \\
\hline Greece & 9.59 & 10.10 & 105.37 \\
\hline Spain & 9.62 & 14.29 & 148.55 \\
\hline France & 11.86 & 13.27 & 111.88 \\
\hline Croatia & - & - & - \\
\hline Italy & 13.10 & 12.72 & 97.04 \\
\hline Cyprus & 9.02 & 8.70 & 96.43 \\
\hline Latvia & 6.64 & 10.97 & 165.15 \\
\hline Lithuania & - & 22.06 & - \\
\hline Luxembourg & 6.73 & 8.75 & 129.98 \\
\hline Hungary & 24.58 & 17.56 & 71.45 \\
\hline Malta & 21.15 & 18.39 & 86.96 \\
\hline Netherlands & 13.95 & 16.08 & 115.31 \\
\hline Austria & 9.26 & 8.09 & 87.44 \\
\hline Poland & 32.02 & 25.54 & 79.77 \\
\hline Portugal & 12.85 & 15.35 & 119.46 \\
\hline Romania & - & - & - \\
\hline Slovenia & 16.91 & 8.12 & 47.99 \\
\hline Slovakia & 46.00 & 31.88 & 69.31 \\
\hline Finland & 12.53 & 12.42 & 99.12 \\
\hline Sweden & 12.46 & 8.75 & 70.21 \\
\hline United Kingdom & 12.00 & 15.37 & 128.15 \\
\hline
\end{tabular}


Table 3. Division of countries into groups (source: own processing)

\begin{tabular}{|c|c|c|c|}
\hline 1. & 2. & 3. & 4. \\
\hline $\begin{array}{l}\text { Belgium } \\
\text { (1) }\end{array}$ & Estonia (5) & Denmark (3) & Czech Republic (2) \\
\hline \multirow{9}{*}{$\begin{array}{l}\text { Nether- } \\
\text { lands (16) }\end{array}$} & Ireland (6) & Germany (4) & Italy (10) \\
\hline & Greece (7) & Cyprus (11) & Hungary (14) \\
\hline & Spain (8) & Austria (17) & Malta (15) \\
\hline & France (9) & Sweden (23) & Poland (18) \\
\hline & Latvia (12) & & Slovenia (20) \\
\hline & $\begin{array}{l}\text { Luxembourg } \\
\text { (13) }\end{array}$ & & Slovakia (21) \\
\hline & $\begin{array}{l}\text { Portugal } \\
\text { (19) }\end{array}$ & & \\
\hline & Finland (22) & & \\
\hline & $\begin{array}{l}\text { United } \\
\text { Kingdom } \\
(24)\end{array}$ & & \\
\hline
\end{tabular}

Belgium and the Netherlands had an above-average logarithm of initial values and an above-average logarithm of the average growth coefficient. They tended to move away from other countries in the share of self-employed foreigners in employed persons from foreign countries. One possible reason for this trend is that in these countries there were favourable conditions for self-employment of foreigners.

Estonia, Ireland, Greece, Spain, France, Latvia, Luxembourg, Portugal, Finland and the United Kingdom had a below-average logarithm of initial values and an aboveaverage logarithm of the average growth coefficient. The countries in this group tended to move to the first group.

Denmark, Germany, Cyprus, Austria and Sweden had a below-average logarithm of initial values and a belowaverage logarithm of the average growth coefficient. They tended to lag behind the other regions. One possible reason for this trend is that in these countries the conditions for self-employment of foreigners have worsened or conditions for employment of foreigners have improved.

The Czech Republic, Italy, Hungary, Malta, Poland, Slovenia and Slovakia had an above-average logarithm of initial values and a below-average logarithm of the average growth coefficient. The countries in this group tended to move to the third group.

We have confirmed that the countries have a trend towards convergence in regard to the share of self-employed foreigners in employed persons from foreign countries. We assume that this tendency can also be due to the pressure of the labour market that shows a lack of labour force.

The share of self-employed foreigners and the average growth coefficient are high in countries characterized by an open economy and significant support for foreign companies (SOPK, 2010).

The share of self-employed foreigners is relatively high in Eastern Europe. On the other hand, their increase is below average compared to the EU. Further research should be aimed at identifying the causes of this development. However, in our analysis it should be pointed out that the trends identified could have been caused by several factors. Further research is needed for further specification.

\section{Conclusions}

The main aim of this article was to identify certain specificity in self-employment of foreigners in EU countries and to find out whether the differences in self-employment of foreigners between countries are diminishing. One sub-objective was to compare EU countries on the basis of the indicators "Number of self-employed foreigners" and "Share of self-employed foreigners in employed persons from foreign countries". Another sub-objective was to determine whether EU countries converge in the share of self-employed foreigners in employed persons from foreign countries.

The highest number of self-employed foreigners was in 2010 in Germany and in 2016 in the United Kingdom. The number of self-employed foreigners in the Slovak Republic was the second lowest in EU countries. However, the share of self-employed foreigners in employed persons from foreign countries in the Slovak Republic was the highest compared to the EU countries analysed. Poland, the Czech Republic and Hungary also had a large share of self-employed foreigners in employed persons from foreign countries.

EU countries show a trend towards convergence in the share of self-employed foreigners in employed persons from foreign countries:

The share of self-employed foreigners and the average growth coefficient are high in countries characterized by an open economy and significant support for foreign companies (SOPK, 2010). The share of self-employed migrants is relatively high in Eastern Europe. On the other hand, their increase is below average compared to the European Union. Further research should be aimed at identifying the causes of this development. It seems that the share of self-employed immigrants is mainly influenced by open economy, which is also adapted to legislation and state administration processes.

\section{References}

Bahna, M. (2012). Intra-EU migration from Slovakia: an evaluation of new economics of labour migration and migrant networks theories. European Societis, 15(3), 388-407.

https://doi.org/10.1080/14616696.2012.707669

Bargerová, Z. (2016). Migration as a social phenomenon: historical, social and legal aspects. https://www.multikulti.sk/clanky/ migracia-ako-spolocensky-fenomen-historicke-socialne-apravne-aspekty

Bilan, Y. (2012). Specificity of border labour migration. Transformations in Business \& Economics, 11(2), 82-97. http://www.transformations.knf.vu.lt/26/article/spec 
Čajka, P., Jaroszewicz, M., \& Strielkowski, W. (2014). Migration Incentives and Flows between Belarus, Moldova, Ukraine and the European Union: a Forecasting Model. Economics and Sociology, 7(4), 11-25. https://doi.org/10.14254/2071-789X.2014/7-4/1

De Luna Gallardo, G., Korneeva, E., \& Strielkowski, W. (2016). Integration of migrants in the EU: lessons and implications for the EU migration policies. Journal of International Studies, 9(2), 244-253. https://doi.org/10.14254/2071-8330.2016/9-2/19

European Economic and Social Committee. (2012). Contribution of migrant entrepreneurs to economy of the EU. SOC/449. https://www.employment.gov.sk/files/slovensky/ministerstvo/ integracia-cudzincov/dokumenty/prinos_podnikatelov_z_radov_pristahovalcov_pre_hospodarstvo_eu.pdf

Eurostat. (2019, 1). Database, 1. 9. 2019. http://ec.europa.eu/eurostat/data/database, lfsa_esgan

Eurostat. (2019, 2). Database, 1. 9. 2019. http://ec.europa.eu/eurostat/data/database, lfsa_pganws

Fraňková, A. (2015). Determining labour shortages and the need for labour migration from third countries in the Slovak Republic. International Organization for Migration (IOM). https:// ec.europa.eu > home-affairs > sites > homeaffairs > files

Fratczak, E. Z. (2016). The demographic crisis and global migration - selected issues. Papers on Global Change, 23(1), 71-87. https://doi.org/10.1515/igbp-2016-0006

Jenkins, R., et al. (2010) International migration of doctors, and its impact on availability of psychiatrists in low and middle income countries. Plos One 4, 5(2). https://journals.plos.org/ plosone/article? id=10.1371/journal.pone.0009049

Jurčová, D. (2008). Labour migration in the Slovak Republic. http://www.infostat.sk/vdc/sk/index .php?option=com_cont ent\&view $=$ article\&id $=16 \&$ Itemid $=16$

Kerr, S. P., \& Kerr, W. R. (2011). Economic impact of immigration: a survey. Working Paper. 09-013. Harvard Business School. www.hbs.edu/faculty/Publication\%20Files/09013_15702a45-fbc3-44d7-be52-477123ee58d0.pdf

Krajňáková, E., \& Vojtovič, S. (2017). Struggles of older workers at the labour market. In Economics \& Sociology, 10(1), 319333. https://www.economics-sociology.eu/?489,en_strugglesof-older-workers-at-the-labour-market

Lapshyna, I. (2012). Transformational changes and challenges for human capital development in the context of Ukrainian Labour Migration. Economics \& Sociology, 5(1), 111-124. https://www.economics-sociology.eu/files/Iryna\%20Lapshyna\%20V5N1.pdf

Libanova, E. (2019). Labour migration from Ukraine: key features, drivers and impact. Economics \& Sociology, 12(1), 313328. https://www.economics-sociology.eu/?657,en_ labourmigration-from-ukraine-key-features-drivers-and-impact
Minařík, B., Borůvková, J., \& Vystrčil, M. (2013). Analýzy v regionálním rozvoji [Analyzes in Regional Development]. Př́ibram: Professional publishing.

OECD. (2014). Is migration good for the economy? Migration Policy Debates. file://D:/články\%20migrácia/OECD\%20Migration\%20Policy\%20Debates\%20Numero\%202.pdf

Refslund, B. (2017). Sectoral variation in consequences of intraEuropean labour migration: how unions and structural conditions matter. Labour Mobility in the Enlarged Single European Market, 32, 73-77. https://doi.org/10.1108/S0195-631020160000032004

Reja, M. S., \& Das, B. (2019). Labour migration within India: motivations and social networks. South Asia Research, 39(2), 125-142. https://doi.org/10.1177/0262728019842018

Simionescu, M., Bilan, Y., Smrčka, L., \& Vincúrová, Z. (2017). The effects of European economic integration and the impact of brexit on the UK immigrants from the CEE countries. E+ M Ekonomie a Management, 20(1), 29-46. https://doi.org/10.15240/tul/001/2017-1-003

Skibiński, A., \& Rączaszek, A. (2017). Economic and demographic effects of external migration in Poland and Slovakia some aspects. European Journal of Sustainable Development, 6(3), 129-140. https://doi.org/10.14207/ejsd.2017.v6n3p129

Slovak Business Agency. (2019). Analysis of business conditions and employment of foreigners. http://www.sbagency.sk/sites/ default/files/msp_v_cislach_v_roku_2015_0.pdf

SOPK. (2010). Guide to setting up a business and craft activity in the European Union - Netherlands. http://webcache.googleusercontent.com/search?q=cache:yoRD2Uy8vLUJ:www. sbagency.sk/sites/default/files/file/podnikanie_v_holandsku. $\mathrm{pdf}+\& \mathrm{~cd}=1 \& \mathrm{hl}=\mathrm{sk} \& \mathrm{ct}=\mathrm{clnk} \& \mathrm{gl}=\mathrm{sk} \& \mathrm{client}=$ firefox $-\mathrm{b}-\mathrm{d}$

Streimikiene, D., Bilan, Y., Jasinskas, E., \& Griksaite, R. (2016). Migration trends in Lithuania and other New EU Member States. Transformations in Business \& Economics, 15(1), 2133. http://www.transformations.knf.vu.lt/37/ed37.pdf

Świerczyńska, K., \& Kliber, A. (2018) African emigration to Europe: social cohesion and inequality Nexus. In Economics \& Sociology, 11(1), 188-204. https://www.economics-sociology. eu/files/16_12_495_\%20swierczynska_kliber.pdf

Vdovtsova, S. (2008). Motivation mechanisms of youth behavior on Ukrainian labour market. Economics \& Sociology, 1(1), 105-108. https://www.economics-sociology.eu/files/16.pdf

Zuk, P., Zuk, P, \& Lisiewicz-Jakubaszko, J. (2019). Labour migration of doctors and nurses and the impact on the quality of health care in Eastern European countries: The Case of Poland. Economic and Labour Relations Review, 30(2), 307-320. https://doi.org/10.1177/1035304619847335 